TESE DE DOUTORADO

\title{
ASPECTOS HISTÓRICOS DO TRABALHO PEDAGÓGICO DOS PRIMEIROS JARDINS DE INFÂNCIA NO ESTADO DO PARANÁ
}

\author{
Autor: Jaqueline Delgado Paschoal \\ Orientadora: Profa. Dra. Maria Cristina Gomes Machado \\ Universidade Estadual de Maringá - UEM \\ Departamento de Fundamentos da Educação, Programa de Pós-Graduação em Educação \\ Ano: 2010
}

\begin{abstract}
RESUMO
Este estudo teve como objetivo principal conhecer, registrar e analisar por meio da legislação os aspectos históricos da organização do trabalho pedagógico dos primeiros Jardins de Infância paranaenses. Justifica-se a intenção do trabalho, pois o movimento de investigar o passado, resgatando as marcas do processo de criação e organização dessas instituições, coloca-se como a possibilidade de dar visibilidade ao processo de constituição desta modalidade educacional, no sentido de perceber os seus condicionantes e as circunstâncias de sua criação. Quanto à demarcação temporal, concentra-se no período de 1862, período em que foi criado o primeiro Jardim de Infância paranaense, e se estende até 1915, ano de aprovação do Código de Ensino que reorganizou a educação da primeira infância no Estado do Paraná. Como metodologia de trabalho, optou-se pelo Método Histórico, já que, por meio dele, é possível compreender os aspectos sociais, econômicos e políticos que se faziam presentes no Brasil e no Estado do Paraná, conforme delimitado anteriormente. Os resultados da pesquisa apontam que existe uma lacuna na história do Paraná sobre as origens dos seus primeiros Jardins de Infância. Pela análise de documentos não oficializados, verificou-se que o Estado do Paraná foi o pioneiro na criação do Primeiro Jardim de Infância particular do Brasil, intitulado "Jardim-Escola", cuja proposta baseou-se na metodologia de Froebel. Esse fato ocorreu em 1862, ainda no Império, na cidade de Castro. Com a República, duas novas instituições foram criadas oficialmente pelo poder público: uma no ano de 1906, intitulada "Maria de Miranda", e a outra em 1911, chamada "Emília Ericksen". Enquanto a primeira optou pela mesma metodologia froebeliana, que prioriza a brincadeira como proposta de trabalho, a segunda buscou como referencial a metodologia montessoriana, que propõe uma organização curricular de acordo com o desenvolvimento infantil. Embora ambas tenham sido inauguradas em um momento em que o discurso republicano defendia a instrução pública como forma de modernização do Estado e alavanca para o desenvolvimento do progresso, vários problemas foram apresentados, entre eles: a falta de vagas, questões de ordem estrutural, articulação inexistente entre os Jardins de Infância e as escolas primárias, ainda que os mesmos dividissem o mesmo espaço físico. Para além dessas questões, o estudo efetuado sinalizou para as particularidades impressas no interior dos Jardins de Infância paranaenses, já que as opções metodológicas reconheciam a infância como período de grandes descobertas
\end{abstract}


na vida da criança e na originalidade do seu pensamento. Em suma, esses espaços de Educação Infantil garantiram vivências educativas naquele momento histórico, configurando-se como ambientes de aprendizagens por meio da organização do trabalho pedagógico.

Palavras-chave: Educação. História da educação. Instituições escolares. Educação infantil. 